\title{
Commentary
}

\section{Challenges at the host-arthropod-coronavirus interface and COVID-19: a One Health approach}

\author{
José de la Fuente ${ }^{1,2, *}$, Isabel G. Fernández de Mera ${ }^{1}$, Christian Gortázar ${ }^{1}$ \\ ${ }^{1}$ SaBio, Instituto de Investigación en Recursos Cinegéticos (Research Institute of Hunting Resources) \\ IREC-CSIC-UCLM-JCCM, 13005 Ciudad Real, Spain, ${ }^{2}$ Department of Veterinary Pathobiology, Center for Veterinary \\ Health Sciences, Oklahoma State University, Stillwater, OK 74078, USA
}

\section{TABLE OF CONTENTS}

\author{
1. Abstract \\ 2. Introduction \\ 3. Possible role of arthropod vectors at the host-SARS-CoV-2 interface \\ 4. Questions regarding SARS-CoV-2 virus variants arising in low-susceptible hosts \\ 5. Perspective and conclusion \\ 6. Author contributions \\ 7. Ethics approval and consent to participate \\ 8. Acknowledgment \\ 9. Funding \\ 10. Conflict of interest \\ 11. References
}

\section{Abstract}

Background: The world faces the challenge posed by the interaction between hosts and Severe Acute Respiratory Syndrome Coronavirus-2 (SARS-CoV-2) with potential role for arthropod vectors, and the effect of SARSCoV-2 variants on acquired immunity, vaccine efficacy and coronavirus disease-19 (COVID-19) pandemic control. Proposal: The characterization of the role played by animal hosts and host-virus interactions is essential to address this challenge. Zoonotic (animal-to-human) and reverse zoonotic (human-to-animal) routes may be involved in virus transmission with a possible still unconfirmed role for arthropod vectors. Herein we propose to consider the risks posed by the possible role of arthropod vectors in COVID-19 and that immunity against SARS-CoV-2 may increase the risk for zoonotic virus transmission. These risks should be considered when evaluating vaccine efficacy and monitoring animal SARS-CoV-2 variants. Conclusion: Virus surveillance, epidemiology, sequencing and evaluation of susceptibility to antibodies and other protective immune mechanisms from vaccinated individuals should be improved. A One Health approach such as the one applied by our group SaBio is necessary for a more effective control of COVID-19 and prevention of future pandemics.

\section{Introduction}

Vaccines against severe acute respiratory syndrome coronavirus 2 (SARS-CoV-2) are a major achievement for the global control of the coronavirus disease 19 pandemic (COVID-19). Recently, identified SARS-CoV2 variants have raised concern about fast-spreading of the virus and their potential effect on limiting vaccine efficacy [1-3]. Although current evidence suggest that vaccines remain effective at least partially against these variants of concern (VOC), the role played by animal hosts is also essential to address this question [4]. SARS-CoV-2 variants produced in low-susceptible and chronically infected hosts may be more effective in evading immunity and producing high viral loads, thus increasing the risk for zoonotic virus transmission [4].

Currently, the most accepted hypothesis is that the COVID-19 pandemic emerged by SARS-CoV-2 transmission from insectivorous bats through other intermediate (bridge) mammals to humans [5]. Natural infections with SARS-CoV-2 have identified several potential animal hosts with evidence of reverse zoonotic (human-to-animal) and sporadic zoonotic (animal-to-human) virus transmission $[4,6,7]$. Based on these results and models for SARSCoV-2 Spike (S)-angiotensin I converting enzyme (ACE) host receptor interactions, animals with close-to-human SACE interactions (e.g., great apes or ruminants) may consti-

Submitted: 10 June 2021 Revised: 19 July 2021 Accepted: 21 July 2021 Published: 30 August 2021

This is an open access article under the CC BY 4.0 license (https://creativecommons.org/licenses/by/4.0/).

(C) 2021 The Author(s). Published by BRI. 
tute effective hosts for maintenance, evolution and zoonotic transmission of virus variants highly infectious in humans. Other animal species susceptible to SARS-CoV-2 but with low S-ACE interaction capacity (e.g., cats or pigs) would be susceptible to reverse zoonotic virus transmission with low risk for human infection [8]. Additionally, modelling interactions between SARS-CoV-2 S-protein and arthropod ACE receptor suggested a possible role for vectors in coronavirus transmission even if low viremia reduces the risk for transmission [9].

Several factors affect the selection/appearance of new virus variants. As other coronaviruses, SARS-CoV-2 acquire amino acid substitutions as a result of the proofreading RNA polymerase [3]. Additionally, these viruses selectively delete small fragments of its RNA that are not corrected by RNA polymerase and may translate into protein modifications [2]. These modifications occur continuously in a recurring pattern of evolution and contribute to virus adaptation to host factors (i.e., receptors) and evasion of immune response [1-3]. Based on these mechanisms, the virus carrying the H69/V70 deletion appeared in Denmark as a virus variant that originated on mink farms and passed to humans, with the capacity to better adapt to minks while evading human antibody response [10]. Additionally, virus variants with various mutations have been isolated from animal hosts [11].

A One Health approach is required to control the COVID-19 pandemic and other infectious diseases with global incidence and for prevention of future pandemics. As defined by the Centers for Disease Control and Prevention (CDC; https://www.cdc.gov/onehealth/basi cs/index.html), "One Health is a collaborative, multisectoral, and transdisciplinary approach working at the local, regional, national and global levels, with the goal of achieving optimal health outcomes recognizing the interconnection between people, animals, plants, and their shared environment” and the World Health Organization (WHO; https://www.who.int/news-room/q-a-detail/on e-health) “One Health is an approach to designing and implementing programmes, policies, legislation and research in which multiple sectors communicate and work together to achieve better public health outcomes". The importance of One Health is reinforced by factors that increase risks of infectious diseases such as (a) growth and expansion of human populations, (b) increased people contact with wild and domestic animals, (c) climate change, (d) deforestation and intensive farming practices, and (e) international travel and trade of people, animals and animal products. For example, the impact of climate change on factors such as vegetation canopy and phenology, host density and abundance of reservoir species affect tick ecology and the spread of tick vectors and transmitted pathogens [12].

In this paper, we propose to consider the risks posed by the possible role of arthropod vectors in COVID19 and in zoonotic virus transmission, and the need to use a One Health approach for a more effective control of COVID-19 and prevention of future pandemics.

\section{Possible role of arthropod vectors at the host-SARS-CoV-2 interface}

Arthropods such as mosquitoes, flies, mites, fleas, lice and ticks can act as vectors of viruses and other pathogens via active biological transmission but also through passive mechanical transmission [9, 13-16] (Table 1, Ref. [17-30]). Biological transmission occurs when vectors transmit pathogens that multiply within their bodies [31, 32]. Mechanical transmission is mediated by vector transfer of pathogens from contaminated exoskeleton, feet, mouth parts or internal organs to host body or sustenance [31].

Animal species susceptible to SARS-CoV-2 with a role as coronavirus hosts and in transmission of the coronavirus [5-7, 33] are also infested or in contact with arthropod vectors (Table 1). Coronaviruses have been previously identified in ticks Ixodes uriae [34] and in unfed cat flea Ctenocephalides felis [35]. The application of experimentally validated models for SARS-CoV-2 S-ACE host receptor interactions support that not only vertebrate hosts, but also arthropod ACE may have the capacity to interact with SARS-CoV-2 S-protein [8, 9, 36]. Additionally, SARSCoV-2 co-receptor integrins [37, 38] have been described in tick salivary glands and cement [39, 40] and in cat flea exoproteome [35, 41]. Cement is secreted by ticks as a complex protein polymerization substance with antimicrobial properties and a role in host attachment and ectoparasite feeding [40]. Recent experiments showed that mosquitoes are not competent vectors for SARS-CoV-2 [42, 43], results that agree with a predicted lower SARS-CoV-2 S-protein: ACE complex stability in insects [9]. Based on these results, it is possible that SARS-CoV-2 may be acquired by arthropod ectoparasites through feeding on infected hosts and may persist not only in contaminated mouthparts or exoskeleton [30], but also inside the vector through interactions with ACE and integrins for transmission to susceptible hosts by blood-meal regurgitation during secondary feeding or after transstadial transmission or inherited virus RNA [9, 35, 44, 45].

Another proposed connection between arthropods and COVID-19 is the immune response to the glycan Gal $\alpha 1-3 G a l$ ( $\alpha$-Gal) [46-50]. Arthropods such as Ixodida ticks and Anopheles mosquitoes synthesize $\alpha$-Gal [51, 52]. The immunoglobulin (Ig) E antibody response to $\alpha$-Gal associated with tick bites results in some individuals in allergic reactions such as delayed anaphylaxis to mammalian meat consumption known as the alphaGal syndrome (AGS) [53-58]. A catastrophic evolutionary event in humans resulted in the inactivation of the $\alpha-1,3$-galactosyltransferase gene and the capacity to produce high antibody titers against $\alpha$-Gal and protective 
Table 1. Examples of passive mechanical pathogen transmission by arthropod vectors.

\begin{tabular}{|c|c|c|c|}
\hline Pathogens & Arthropod vectors & Hosts & References \\
\hline Lumpy skin disease virus, LSDV & Amblyomma hebraeum & $\begin{array}{c}\text { Wild ungulates } \\
\text { Domestic ruminants }\end{array}$ & [17] \\
\hline Rickettsia felis & Ctenocephalides felis & $\begin{array}{c}\text { Cat } \\
\text { Dog } \\
\text { Opossum } \\
\text { Raccoon } \\
\text { Rodent } \\
\text { Human }\end{array}$ & [18] \\
\hline Anaplasma marginale & Stomoxys calcitrans & Cattle & [19-21] \\
\hline Human immunodeficiency virus 1, HIV-1 & Ornithodoros moubata & Human & [22] \\
\hline African Swine Fever Virus, ASFV & Stomoxys calcitrans & Pig & [23] \\
\hline Porcine reproductive and respiratory syndrome virus, PRRS & Musca domestica & Pig & [24] \\
\hline Avian influenza virus H5N1 & Musca domestica & Chicken & [25] \\
\hline Equine infectious anemia (EIA) RNA virus & $\begin{array}{l}\text { Tabanus sp. } \\
\text { Stomoxys calcitrans }\end{array}$ & $\begin{array}{c}\text { Horse } \\
\text { Donkey } \\
\text { Mule }\end{array}$ & [26] \\
\hline Shigella spp. & Musca domestica & Human & [27] \\
\hline Enterovirus C poliovirus and Coxsackievirus & Musca domestica & Human & [28] \\
\hline Hepatitis A virus & Blattella germanica & Human & [28] \\
\hline Turkey coronavirus & Musca domestica & Turkey & [29] \\
\hline SARS-CoV-2 & Musca domestica & $\begin{array}{c}\text { Human } \\
\text { Companion animals }\end{array}$ & [30] \\
\hline
\end{tabular}

against pathogens including viruses with this modification on their surface $[59,60]$. Therefore, despite the risks associated with anti- $\alpha$-Gal IgE-mediated allergic reactions [61], the immunization with $\alpha$-Gal results in protection against pathogen infection and tick infestations through protective antibody response and other immune mechanisms [49, 52, 62, 63]. Accordingly, the IgM/IgG type antibodies against $\alpha$-Gal, naturally produced in response to gut bacterial microbiota [64], and other immune mechanisms have been associated with protective response to SARSCoV-2 infection and transmission and COVID-19 symptomatology [46, 48-50]. These mechanisms include opsonization of pathogens with $\alpha$-Gal or structurally related glycans on their surface, B-cell maturation, macrophage response, complement system, and upregulation of proinflammatory cytokines through the TLR2/nuclear factor $\mathrm{kB}$ (NF-kB) innate immune pathway with possible implications in trained immunity $[46-49,63]$. The SARS-CoV-2 as other viruses do not synthesize $\alpha$-Gal but this and structurally related glycans may be incorporated on surface proteins from the host/vector cells to activate protective immune mechanisms in response to $\alpha-\mathrm{Gal}$ [46-50, 52].

Altogether, these findings support a possible role for arthropods at the host-coronavirus interface with potential implications as low-susceptible non-mammalian hosts and biological and/or passive vectors for SARS-CoV-2, possibilities that need to be evaluated in future research [9, 30, 35, 65-67].

\section{Questions regarding SARS-CoV-2 virus variants arising in low-susceptible hosts}

Some virus variants arising in low-susceptible hosts with modifications in S and other proteins could increase fitness and evade or reduce the efficacy of human immune response to vaccination and infection with currently circulating virus variants. Additionally, the role of integrins as co-receptors for SARS-CoV-2 cell attachment [38] and a putative implication of arthropod vectors [35] may also affect animal host susceptibility to infection with the selection of new virus variants [37]. Virus protein modifications could be related to genetic or post-translational modifications (e.g., glycosylation or ADP-ribosylation) [46, 68, 69]. Currently, these SARS-CoV-2 variants potentially arising in low-susceptible hosts do not constitute a major risk for humans. Nevertheless, in a growing immunized population after infection or vaccination, variants produced in lowsusceptible hosts may be more effective in evading immunity, thus increasing the risk for zoonotic virus transmission. For example, a virus variant with high fitness in a low-susceptible host may not be efficiently transmitted to humans as compared with currently circulating variants. However, a genetic and/or post-translational modification in a virus variant arising from a low-susceptible host could acquire the capacity to evade human immune response and thus establish infection in individuals protected against currently circulating virus variants (Fig. 1). The evolutionary history of coronaviruses suggests that SARS-CoV-2 infectivity derived from adaptation in bats and not humans [69]. 


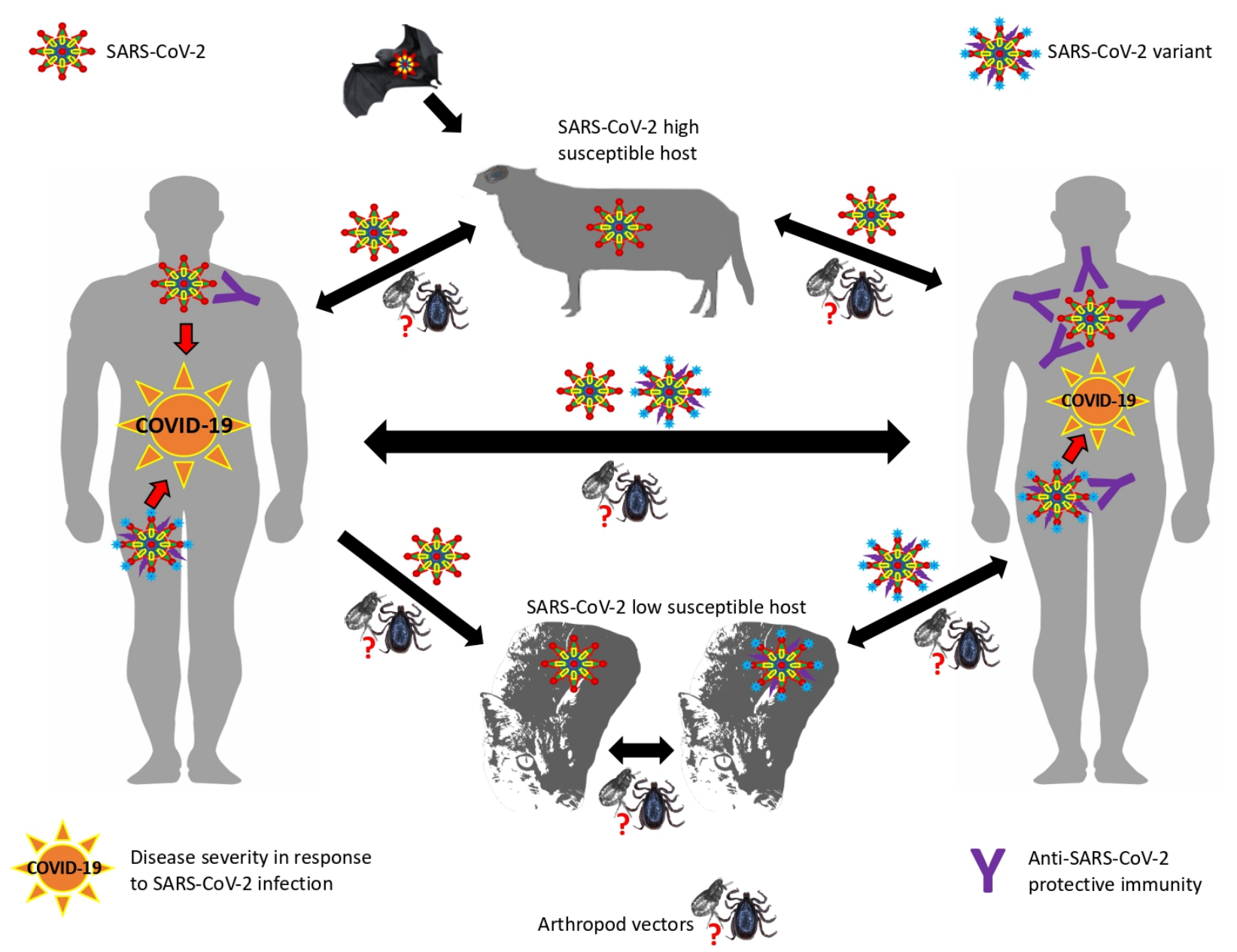

Fig. 1. Increased risk for zoonotic virus transmission. SARS-CoV-2 variants produced in low-susceptible and chronically infected hosts may be more effective in evading immunity and with higher human-to-human transmission. SARS-CoV-2 high and low susceptible hosts are only shown as representative species.

Furthermore, these new virus variants may be also susceptible to reverse zoonotic transmission to animal hosts for maintenance and appearance of new variants [4]. Despite the controversy regarding the origin of SARS-CoV-2 [70], understanding the role of low-susceptible animal hosts such as ferrets in coronavirus infection, adaptation and arising of new virus variants is important to control COVID-19 and other emerging infectious diseases [71-75].

Based on the questions related to the appearance of new virus VOC such as Alpha (B.1.1.7), Beta (B.1.351), Gamma (P.1) and Delta (B.1.617.2) (https://www.who. int/en/activities/tracking-SARS-CoV-2-variants/) [76], the ECDC [77] recommends avoiding prolonged situations with high proportion of the population partially susceptible to virus infection, surveillance of zoonotic SARS-CoV2 transmission and monitorization and isolation of individuals with long-lasting infection.

\section{Perspective and conclusion}

A global One Health approach is required for the prevention and control of infectious diseases with a transdisciplinary research between ecology, biotechnology and human/animal health. This approach requires the international collaboration between scientific, industrial and health partners. As an example, our group SaBio (from "Sanidad \& Biotecnología” which translates into "Health \& Biotechnology") applies this approach for the study of infectious diseases such as those caused by ticks and tickborne pathogens or mycobacteria e.g., $[78,79]$. With the emergence of COVID-19, the challenge posed by this pandemic should be approached with a global One Health perspective by combining research on environmental and epidemiological factors, virus animal hosts and transmission, and human immune response [6, 9, 35, 36, 46, 48, 75, 8084] (Fig. 2). These results advance research for the development of interventions for the control of current COVID19 and future pandemics including SARS-CoV-2 diagnostic and environmental monitoring, epidemiological stud- 


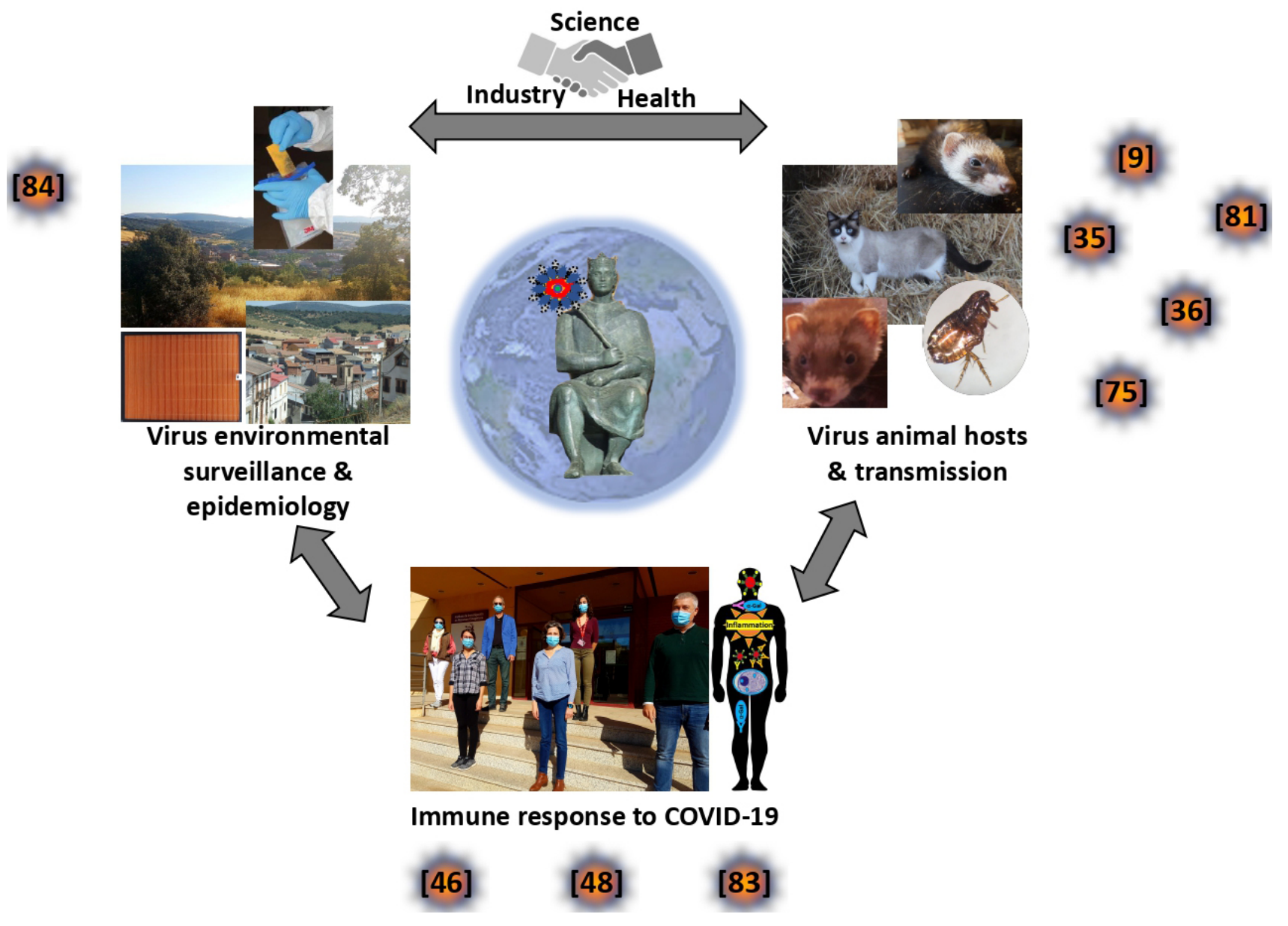

Fig. 2. SaBio on COVID-19: A global One Health approach. Our group, SaBio, applies a global One Health approach in research for the control of infectious diseases. Regarding COVID-19, we have applied this approach by developing research in three areas: (a) SARS-CoV-2 environmental surveillance and epidemiology, (b) virus animal hosts and transmission, and (c) immune response to COVID-19. The results (illustrated in publications $[9,35,36,46,48,75,81,83,84]$ ) have contributed to the characterization of disease epidemiology and immune response mechanisms with a possible impact on the development of prevention, diagnostic, prognostic and therapeutic interventions. Images courtesy of the authors.

ies with case mapping, contact tracing, potential role of animal hosts and arthropod vectors, palliative treatments and prognostic biomarkers, and personalized medicine including the use of $\alpha$-Gal-containing prebiotics/probiotics $[6,9,35,36,46,48,75,80-84]$.

As highlighted in this paper, host and virus derived factors are the key drivers of the COVID-19 pandemic [8, 35, 85, 86], and non-human hosts may gain protagonism in the near future. The information about viral host ranges and associations between known viruses and susceptible hosts is limited but key to prevent future pandemics [87]. In addition to their role in the generation of new virus variants, relaxing measures in response to pandemic control may also increase human-to-animal contact in both urban and rural settings. These risks are underestimated and should be considered when evaluating vaccine efficacy in relation to the potential role of animal reservoirs and zoonotic virus transmission. SARS-CoV-2 surveillance at the human-animal interface, sequencing and evaluation of susceptibility to antibodies from vaccinated individuals should be improved [67, 71-77, 85-89]. The direct and indirect impact of COVID-19 on animal health should also be considered [6, 90, 91]. A One Health approach searching a balanced interaction of humanity with nature and a more holistic approach to disease control is necessary for a more effective prevention of future pandemics [92].

\section{Author contributions}

Conceptualization, JF and CG; investigation, JF, IGFM and CG; writing-original draft preparation, JF; writing - review and editing, JF, IGFM and CG; visualization, JF; All authors have read and agreed to the published version of the manuscript.

\section{Ethics approval and consent to participate}

Not applicable. 


\section{Acknowledgment}

We thank members of SaBio and collaborators worldwide for their contributions to COVID-19 research and acknowledge the University of Castilla La Mancha (UCLM, Spain) for support to Group SaBio.

\section{Funding}

This research received no external funding.

\section{Conflict of interest}

The authors declare no conflict of interest.

\section{References}

[1] Callaway E. Could new COVID variants undermine vaccines? Labs scramble to find out. Nature. 2021; 589: 177-178.

[2] McCarthy KR, Rennick LJ, Nambulli S, Robinson-McCarthy LR, Bain WG, Haidar G, Duprex WP. Recurrent deletions in the SARS-CoV-2 spike glycoprotein drive antibody escape. Science. 2021; 371: 1139-1142.

[3] Thomson EC, Rosen LE, Shepherd JG, Spreafico R, da Silva Filipe A, Wojcechowskyj JA, et al. Circulating SARS-CoV-2 spike N439K variants maintain fitness while evading antibodymediated immunity. Cell. 2021; 184: 1171-1187. e20.

[4] Banerjee A, Mossman K, Baker ML. Zooanthroponotic potential of SARS-CoV-2 and implications of reintroduction into human populations. Cell Host \& Microbe. 2021; 29: 160-164.

[5] Zhou P, Yang XL, Wang XG, Hu B, Zhang L, Zhang W, et al. A pneumonia outbreak associated with a new coronavirus of probable bat origin. Nature. 2020; 579: 270-273.

[6] Delahay RJ, de la Fuente J, Smith GC, Sharun K, Snary EL, Flores Girón L, et al. Assessing the risks of SARS-CoV-2 in wildlife. One Health Outlook. 2021; 3: 7.

[7] Hedman HD, Krawczyk E, Helmy YA, Zhang L, Varga C. Host diversity and potential transmission pathways of SARS-CoV-2 at the human-animal interface. Pathogens. 2021; 10: 180.

[8] Lam SD, Bordin N, Waman VP, Scholes HM, Ashford P, Sen N, et al. SARS-CoV-2 spike protein predicted to form complexes with host receptor protein orthologues from a broad range of mammals. Scientific Reports. 2020; 10: 16471.

[9] Lam SD, Ashford P, Díaz-Sánchez S, Villar M, Gortázar C, de la Fuente J, Orengo C. Arthropod ectoparasites have potential to bind SARS-CoV-2 via ACE. Viruses. 2021; 13: 708.

[10] Oude Munnink BB, Sikkema RS, Nieuwenhuijse DF, Molenaar RJ, Munger E, Molenkamp R, et al. Transmission of SARSCoV-2 on mink farms between humans and mink and back to humans. Science. 2021; 371: 172-177.

[11] Elaswad A, Fawzy M, Basiouni S, Shehata AA. Mutational spectra of SARS-CoV-2 isolated from animals. PeerJ. 2020; 8: e10609.

[12] Sonenshine DE. Range expansion of tick disease vectors in North America: Implications for spread of tick-borne disease. International Journal of Environmental Research and Public Health. 2018; 15: 478.

[13] Kazimírová M, Thangamani S, Bartíková P, Hermance M, Holíková V, Štibrániová I, Nuttall PA. Tick-Borne viruses and biological processes at the tick-host-virus interface. Frontiers in Cellular and Infection Microbiology. 2017; 7: 339.

[14] Jones L, Davies C, Steele G, Nuttall P. A novel mode of arbovirus transmission involving a nonviremic host. Science. 1987; 237: 775-777.
[15] Chihota CM, Rennie LF, Kitching RP, Mellor PS. Mechanical transmission of lumpy skin disease virus by Aedes aegypti (Diptera: Culicidae). Epidemiology and Infection. 2001; 126: 317-321.

[16] Tuppurainen ESM, Lubinga JC, Stoltsz WH, Troskie M, Carpenter ST, Coetzer JAW, et al. Mechanical transmission of lumpy skin disease virus by Rhipicephalus appendiculatus male ticks. Epidemiology and Infection. 2013; 141: 425-430.

[17] Lubinga JC, Tuppurainen ESM, Mahlare R, Coetzer JAW, Stoltsz WH, Venter EH. Evidence of Transstadial and Mechanical Transmission of Lumpy Skin Disease Virus by Amblyomma hebraeum Ticks. Transboundary and Emerging Diseases. 2015; 62: 174-182.

[18] Brown LD, Banajee KH, Foil LD, Macaluso KR. Transmission mechanisms of an emerging insect-borne rickettsial pathogen. Parasites \& Vectors. 2016; 9: 237

[19] de la Fuente J, Van Den Bussche RA, Kocan KM. Molecular phylogeny and biogeography of North American isolates of Anaplasma marginale (Rickettsiaceae: Ehrlichieae). Veterinary Parasitology. 2001; 97: 65-76.

[20] Scoles GA, Broce AB, Lysyk TJ, Palmer GH. Relative efficiency of biological transmission of Anaplasma marginale (Rickettsiales: Anaplasmataceae) by Dermacentor andersoni (Acari: Ixodidae) compared with mechanical transmission by Stomoxys calcitrans (Diptera: Muscidae). Journal of Medical Entomology. 2005; 42: 668-675.

[21] Kocan KM, de la Fuente J, Blouin EF, Coetzee JF, Ewing SA The natural history of Anaplasma marginale. Veterinary Parasitology. 2010; 167: 95-107.

[22] Humphery-Smith I, Donker G, Turzo A, Chastel C, SchmidtMayerova $\mathrm{H}$. Evaluation of mechanical transmission of HIV by the African soft tick, Ornithodoros moubata. AIDS. 1993; 7: 341-347.

[23] Bonnet SI, Bouhsira E, De Regge N, Fite J, Etoré F, Garigliany $\mathrm{MM}$, et al. Putative role of arthropod vectors in African swine fever virus transmission in relation to their bio-ecological properties. Viruses. 2020; 12: 778.

[24] Pitkin A, Deen J, Otake S, Moon R, Dee S. Further assessment of houseflies (Musca domestica) as vectors for the mechanical transport and transmission of porcine reproductive and respiratory syndrome virus under field conditions. Canadian Journal of Veterinary Research. 2009; 73: 91-96.

[25] Wanaratana S, Amonsin A, Chaisingh A, Panyim S, Sasipreeyajan J, Pakpinyo S. Experimental assessment of houseflies as vectors in avian influenza subtype H5N1 transmission in chickens. Avian Diseases. 2013; 57: 266-272.

[26] Espasandin AG, Cipolini MF, Forletti A, Díaz S, Soto J, Martínez DE, et al. Comparison of serological techniques for the diagnosis of equine infectious Anemia in an endemic area of Argentina. Journal of Virological Methods. 2021; 291: 114101.

[27] Levine OS, Levine MM. Houseflies (Musca domestica) as mechanical vectors of Shigellosis. Clinical Infectious Diseases. 1991; 13: 688-696.

[28] Sarwar M. Insect vectors involving in mechanical transmission of human pathogens for serious diseases. International Journal of Bioinformatics and Biomedical Engineering. 2015; 1: 300-306.

[29] Calibeo-Hayes D, Denning SS, Stringham SM, Guy JS, Smith LG, Watson DW. Mechanical transmission of turkey coronavirus by domestic houseflies (Musca domestica Linnaeaus). Avian Diseases. 2003; 47: 149-153.

[30] Balaraman V, Drolet BS, Mitzel DN, Wilson WC, Owens J, Gaudreault NN, et al. Mechanical transmission of SARS-CoV-2 by house flies. Parasites \& Vectors. 2021; 14: 214.

[31] Randolph SE. Ticks are not Insects: Consequences of contrasting vector biology for transmission potential. Parasitology Today. 1998; 14: 186-192.

[32] Hornok S, Hofmann-Lehmann R, de Mera IGF, Meli ML, Elek V, Hajtós I, et al. Survey on blood-sucking lice (Phthiraptera: Anoplura) of ruminants and pigs with molecular detection of 
Anaplasma and Rickettsia spp. Veterinary Parasitology. 2010; 174: 355-358.

[33] Shi J, Wen Z, Zhong G, Yang H, Wang C, Huang B, et al. Susceptibility of ferrets, cats, dogs, and other domesticated animals to SARS-coronavirus 2. Science. 2020; 368: 1016-1020.

[34] Traavik T, Mehl R. Tick-borne viruses in Norway. Medical Biology. 1975; 53: 621-624.

[35] Villar M, Fernández de Mera IG, Artigas-Jerónimo S, Contreras M, Gortázar C, de la Fuente J. Coronavirus in cat flea: findings and questions regarding COVID-19. Parasites \& Vectors. 2020; 13: 409.

[36] de la Fuente J, Pastor Comín JJ, Gortázar C. The sound of host-SARS-CoV-2 molecular interactions. Innovation. 2021; 2: 100126.

[37] Oliveira LG, Peron JPS. Viral receptors for flaviviruses: not only gatekeepers. Journal of Leukocyte Biology. 2019; 106: 695701.

[38] Mészáros B, Sámano-Sánchez H, Alvarado-Valverde J, Čalyševa J, Martínez-Pérez E, Alves R, et al. Short linear motif candidates in the cell entry system used by SARS-CoV-2 and their potential therapeutic implications. Science Signaling. 2021; 14: eabd0334.

[39] Cugini C, Medrano M, Schwan TG, Coburn J. Regulation of expression of the Borrelia burgdorferi beta (3)-chain integrin ligand, P66, in ticks and in culture. Infection and Immunity. 2003; 71: 1001-1007.

[40] Villar M, Pacheco I, Merino O, Contreras M, Mateos-Hernández L, Prado E, et al. Tick and host derived compounds detected in the cement complex substance. Biomolecules. 2020; 10: 555.

[41] Contreras M, Villar M, Artigas-Jerónimo S, Kornieieva L, Mytrofanov S, de la Fuente J. A reverse vaccinology approach to the identification and characterization of Ctenocephalides felis candidate protective antigens for the control of cat flea infestations. Parasites \& Vectors. 2018; 11: 43.

[42] Huang YS, Vanlandingham DL, Bilyeu AN, Sharp HM, Hettenbach SM, Higgs S. SARS-CoV-2 failure to infect or replicate in mosquitoes: an extreme challenge. Scientific Reports. 2020; 10 : 11915.

[43] Fortuna C, Montarsi F, Severini F, Marsili G, Toma L, Amendola A, et al. The common European mosquitoes Culex pipiens and Aedes albopictus are unable to transmit SARS-CoV-2 after a natural-mimicking challenge with infected blood. Parasites \& Vectors. 2021; 14: 76.

[44] de la Fuente J, Kocan KM, Almazán C, Blouin EF. RNA interference for the study and genetic manipulation of ticks. Trends in Parasitology. 2007; 23: 427-433.

[45] Zhu KY, Palli SR. Mechanisms, Applications, and Challenges of Insect RNA Interference. Annual Review of Entomology. 2020; 65: 293-311.

[46] Hodžić A, de la Fuente J, Cabezas-Cruz A. COVID-19 in the Developing World: is the Immune Response to $\alpha$-Gal an Overlooked Factor Mitigating the Severity of Infection? ACS Infectious Diseases. 2020; 6: 3104-3108.

[47] Galili U. Host synthesized carbohydrate antigens on viral glycoproteins as "Achilles' heel" of viruses contributing to anti-viral immune protection. International Journal of Molecular Sciences. 2020; 21: 6702

[48] Urra JM, Ferreras-Colino E, Contreras M, Cabrera CM, Fernández de Mera IG, Villar M, et al. The antibody response to the glycan $\alpha$-Gal correlates with COVID-19 disease symptoms. Journal of Medical Virology. 2021; 93: 2065-2075.

[49] de la Fuente J, Gortázar C, Cabezas-Cruz A. Immunity to glycan $\alpha$-Gal and possibilities for the control of COVID-19. Immunotherapy. 2021; 13: 185-188.

[50] Chen J. SARS-CoV-2 replicating in nonprimate mammalian cells probably have critical advantages for COVID-19 vaccines due to anti-Gal antibodies: a minireview and proposals. Journal of Medical Virology. 2021; 93: 351-356.
[51] Cabezas-Cruz A, Espinosa PJ, Alberdi P, Šimo L, Valdés JJ, Mateos-Hernández L, et al. Tick galactosyltransferases are involved in $\alpha$-Gal synthesis and play a role during Anaplasma phagocytophilum infection and Ixodes scapularis tick vector development. Scientific Reports. 2018; 8: 14224.

[52] Cabezas-Cruz A, Hodžić A, Mateos-Hernández L, Contreras M, de la Fuente J. Tick-human interactions: from allergic klendusity to the $\alpha$-Gal syndrome. Biochemical Journal. 2021; 478: 1783-1794.

[53] Commins SP, Satinover SM, Hosen J, Mozena J, Borish L, Lewis BD, et al. Delayed anaphylaxis, angioedema, or urticaria after consumption of red meat in patients with IgE antibodies specific for galactose-alpha-1,3-galactose. Journal of Allergy and Clinical Immunology. 2009; 123: 426-433.

[54] Commins SP, Kelly LA, Rönmark E, James HR, Pochan SL, Peters EJ, et al. Galactose- $\alpha$-1,3-galactose-specific IgE is associated with anaphylaxis but not asthma. American Journal of Respiratory and Critical Care Medicine. 2012; 185: 723-730.

[55] Commins SP, James HR, Kelly LA, Pochan SL, Workman LJ, Perzanowski MS, et al. The relevance of tick bites to the production of IgE antibodies to the mammalian oligosaccharide galactose- $\alpha$-1,3-galactose. Journal of Allergy and Clinical Immunology. 2011; 127: 1286-1293.e6.

[56] Platts-Mills TAE, Schuyler AJ, Tripathi A, Commins SP. Anaphylaxis to the carbohydrate side chain alpha-gal. Immunology and Allergy Clinics of North America. 2015; 35: 247-260.

[57] Fischer J, Yazdi AS, Biedermann T. Clinical spectrum of $\alpha$-Gal syndrome: from immediate-type to delayed immediate-type reactions to mammalian innards and meat. Allergo Journal International. 2016; 25: 55-62.

[58] Cabezas-Cruz A, Hodžić A, Román-Carrasco P, MateosHernández L, Duscher GG, Sinha DK, et al. Environmental and molecular drivers of the $\alpha$-Gal syndrome. Frontiers in Immunology. 2019; 10: 1210.

[59] Galili U. Significance of the evolutionary $\alpha 1,3$ galactosyltransferase (GGTA1) gene inactivation in preventing extinction of apes and old world monkeys. Journal of Molecular Evolution. 2015; 80: 1-9.

[60] Galili U. Evolution in primates by "Catastrophic-selection" interplay between enveloped virus epidemics, mutated genes of enzymes synthesizing carbohydrate antigens, and natural anticarbohydrate antibodies. American Journal of Physical Anthropology. 2019; 168: 352-363.

[61] Wilson JM, Platts-Mills TAE, Keshavarz B. Reply to: the antibody response to the glycan $\alpha$-Gal correlates with COVID-19 symptoms. Journal of Medical Virology. 2021; 93: 5219-5220.

[62] Mateos-Hernández L, Obregón D, Maye J, Borneres J, Versille $\mathrm{N}$, de la Fuente J, et al. Anti-tick microbiota vaccine impacts Ixodes ricinus performance during feeding. Vaccines. 2020; 8: 702.

[63] Hodžić A, Mateos-Hernández L, de la Fuente J, Cabezas-Cruz A. A-Gal-Based Vaccines: Advances, Opportunities, and Perspectives. Trends in Parasitology. 2020; 36: 992-1001.

[64] Galili U, Mandrell RE, Hamadeh RM, Shohet SB, Griffiss JM. Interaction between human natural anti-alpha-galactosyl immunoglobulin $\mathrm{G}$ and bacteria of the human flora. Infection and Immunity. 1988; 56: 1730-1737.

[65] Ismail M, Verma AK, Abdulkadir A, Kumar A, Dhawan DK, Bolya K, et al. Possible Mechanical Transmission of SARSCoV-2 Causing COVID-19 by Insects: Infection, Prevention, Implications, and Control. Open Journal of Medical Microbiology. 2020; 10: 89-101.

[66] Dehghani R, Kassiri H. A brief review on the possible role of houseflies and cockroaches in the mechanical transmission of coronavirus disease 2019 (COVID-19). Archives of Clinical Infectious Diseases. 2020; 15: e102863.

[67] Alfredo M, Wilfrido C, Rosa B. Can house flies mechanically carry and/or transport sars-cov-2? International Journal of Clinical Virology. 2020; 4: 076-078. 
[68] Sun Z, Ren K, Zhang X, Chen J, Jiang Z, Jiang J, et al. Mass Spectrometry Analysis of Newly Emerging Coronavirus HCoV19 Spike Protein and Human ACE2 Reveals Camouflaging Glycans and Unique Post-Translational Modifications. Engineering. 2020. (in press)

[69] MacLean OA, Lytras S, Weaver S, Singer JB, Boni MF, Lemey $\mathrm{P}$, et al. Natural selection in the evolution of SARS-CoV-2 in bats created a generalist virus and highly capable human pathogen. PLOS Biology. 2021; 19: e3001115.

[70] Bloom JD, Chan YA, Baric RS, Bjorkman PJ, Cobey S, Deverman BE, et al. Investigate the origins of COVID-19. Science. 2021; 372: 694.

[71] Beale DJ, Shah R, Karpe AV, Hillyer KE, McAuley AJ, Au GG, et al. Metabolic profiling from an asymptomatic ferret model of SARS-CoV-2 infection. Metabolites. 2021; 11: 327.

[72] Sawatzki K, Hill NJ, Puryear WB, Foss AD, Stone JJ, Runstadler JA. Host barriers to SARS-CoV-2 demonstrated by ferrets in a high-exposure domestic setting. Proceedings of the National Academy of Sciences. 2021; 118: e2025601118.

[73] Royce K. Application of a novel mathematical model to identify intermediate hosts of SARS-CoV-2. Journal of Theoretical Biology. 2021; 526: 110761.

[74] Menachery VD, Yount BL, Debbink K, Agnihothram S, Gralinski LE, Plante JA, et al. A SARS-like cluster of circulating bat coronaviruses shows potential for human emergence. Nature Medicine. 2015; 21: 1508-1513.

[75] Gortázar C, Barroso-Arévalo S, Ferreras-Colino E, Isla J, de la Fuente G, Rivera B, et al. Natural SARS-CoV-2 infection in kept ferrets, Spain. Emerging Infectious Diseases. 2021; 27: 19941996.

[76] Zhang J, Zhang Y, Kang J, Chen S, He Y, Han B, et al. Potential transmission chains of variant B.1.1.7 and co-mutations of SARS-CoV-2. Cell Discovery. 2021; 7: 44.

[77] ECDC (European Centre for Disease Prevention and Control). SARS-CoV-2 (increased circulation of variants of concern and vaccine rollout in the EU/EEA. 2021. Available at: https://www.ecdc.europa.eu/sites/default/files/documen ts/RRA-covid-19-14th-update-15-feb-2021.pdf (Accessed: 20 May 2021).

[78] Pérez de León AA, Strickman DA, Knowles DP, Fish D, Thacker E, de la Fuente J, et al. One Health approach to identify research needs in bovine and human babesioses: workshop report. Parasites \& Vectors. 2010; 3: 36.

[79] Balseiro A, Thomas J, Gortázar C, Risalde MA. Development and challenges in animal tuberculosis vaccination. Pathogens. 2020; 9: 472.

[80] Sharun K, Dhama K, Pawde AM, Gortázar C, Tiwari R, BonillaAldana DK, et al. SARS-CoV-2 in animals: potential for unknown reservoir hosts and public health implications. Veterinary Quarterly. 2021; 41: 181-201.

[81] European Food Safety Authority and European Centre for Disease Prevention and Control, Boklund A, Gortázar C, Pasquali $\mathrm{P}$, Roberts $\mathrm{H}$, Nielsen SS, et al. Monitoring of SARS-CoV-2 infection in mustelids. EFSA Journal. 2021; 19: e06459.
[82] de la Fuente J, Bedia J, Gortázar C. Visual communication and learning from COVID-19 to advance preparedness for pandemics. Exploration of Medicine. 2020; 1: 244-247.

[83] de la Fuente J, Armas O, Sánchez-Rodríguez L, Gortázar C, Lukashev AN; COVID-BCG Collaborative Working Group. Citizen science initiative points at childhood BCG vaccination as a risk factor for COVID-19. Transboundary and Emerging Diseases. 2021. (in press)

[84] Fernández-de-Mera IG, Rodríguez del-Río FJ, Fuente J, PérezSancho M, Hervás D, Moreno I, et al. Detection of environmental SARS-CoV-2 RNA in a high prevalence setting in Spain. Transboundary and Emerging Diseases. 2021; 68: 1487-1492.

[85] Gortázar C, del-Río FJR, Domínguez L, de la Fuente J. Host or pathogen-related factors in COVID-19 severity? Lancet. 2020; 396: 1396-1397.

[86] Yan L, Yi J, Huang C, Zhang J, Fu S, Li Z, et al. Rapid Detection of COVID-19 Using MALDI-TOF-Based Serum Peptidome Profiling. Analytical Chemistry. 2021; 93: 4782-4787.

[87] Wardeh M, Blagrove MSC, Sharkey KJ, Baylis M. Divide-andconquer machine-learning integrates mammalian and viral traits with network features to predict virus-mammal associations. Nature Communications. 2021; 12: 3954.

[88] Rubin R. COVID-19 Vaccines vs Variants-Determining how much Immunity is enough. Journal of the American Medical Association. 2021; 325: 1241-1243.

[89] Pekar J, Worobey M, Moshiri N, Scheffler K, Wertheim JO. Timing the SARS-CoV-2 index case in Hubei province. Science. 2021; 372: 412-417.

[90] Usui R, Sheeran LK, Asbury AM, Blackson M. Impacts of the COVID-19 pandemic on mammals at tourism destinations: a systematic review. Mammal Review. 2021. (in press)

[91] Gortázar C, de la Fuente J. COVID-19 is likely to impact animal health. Preventive Veterinary Medicine. 2020; 180: 105030.

[92] Gortazar C, Reperant LA, Kuiken T, de la Fuente J, Boadella M, Martínez-Lopez B, et al. Crossing the interspecies barrier: opening the door to zoonotic pathogens. PLOS Pathogens. 2014; 10: e1004129.

Abbreviations: VOC, variants of concern; S; Spike; ACE, angiotensin I converting enzyme 2; $\alpha$-Gal, Gal $\alpha 1-3 \mathrm{Gal}$.

Keywords: COVID-19; SARS-CoV-2; Arthropod; Host; Immune response; Virus variants; Vaccination; Epidemiology

Send correspondence to: José de la Fuente, SaBio, Instituto de Investigación en Recursos Cinegéticos (Research Institute of Hunting Resources) IREC-CSICUCLM-JCCM, 13005 Ciudad Real, Spain, Department of Veterinary Pathobiology, Center for Veterinary Health Sciences, Oklahoma State University, Stillwater, OK 74078, USA, E-mail: jose_delafuente@yahoo.com 